\title{
Cenozoic silicoflagellate skeletal morphology: a review and suggested terminology
}

\author{
Kevin McCartney ${ }^{1 *}$ \& Jakub Witkowski ${ }^{2}$ \\ ${ }^{1}$ Department of Environmental Science and Sustainability, University of Maine at Presque Isle, Presque Isle, ME 04769, USA \\ ${ }^{2}$ Geology and Palaeogeography Unit, Faculty of Geosciences, University of Szczecin, ul. Mickiewicza 18, 70-383 Szczecin, \\ Poland \\ *Correspondence: kevin.mccartney@maine.edu
}

\begin{abstract}
Silicoflagellate skeletons are made up of siliceous components that interconnect through triple-junctions to form a basket-shaped design made of basal and apical structures. The skeletal framework has a domal shape that can be paired with another to form a double skeleton. For Cenozoic skeletal morphologies, the basal structure consists of a ring of polygonal shape that often includes spines at the basal corners that are directed radially away from the double-skeleton central point, and pikes that point towards the apical axis. The apical structure is made up of elements of less thickness that are connected to the basal ring by struts. The skeletal components of the silicoflagellate conform to a consistently applied set of rules. There is a need to standardize silicoflagellate descriptive terminology in light of recent studies and detailed examination of the elements, spines and pikes that comprise Cenozoic skeletons. Here we review established and recently defined terminology that relates to silicoflagellate skeletons and suggest terminology to standardize future descriptive work.
\end{abstract}

Keywords: silicoflagellates, terminology, skeleton, Cenozoic

Received 18 August 2015; revised 7 March 2016; accepted 19 March 2016

Silicoflagellates are a group of single-celled marine heterokont algae that possess a siliceous skeletal latticework, composed of hollow, rod-shaped components, during a portion of their life history. Our knowledge of the fossil record of silicoflagellates begins in the late Early Cretaceous (Albian) with an already diverse assemblage (McCartney et al. 2014a), which suggests an earlier period of diversification that is as yet unknown. Late Cretaceous and early Cenozoic silicoflagellate assemblages show a high morphological diversity, which saw a gradual decline over the Neogene. Only three genera, Dictyocha Ehrenberg, Stephanocha McCartney \& Jordan (previously known as Distephanus Stöhr, see Jordan \& McCartney 2015) and Octactis Schiller, are extant (McCartney et al. 2014b; Abe et al. 2015). Silicoflagellate skeletons also exhibit occasional extreme variability - what Deflandre (1950) called 'plasticity' - that often additionally complicates taxonomic interpretations.

Throughout their stratigraphic record, silicoflagellate skeletons display simple geometric patterns, yet descriptive terminology is not standardized and varies between workers. The first illustration of silicoflagellate skeletal terminology was by Lemmermann (1908) and subsequent workers introduced additional terms (Gemeinhardt 1930; Marshall 1934; Deflandre 1950; Gleser 1966; Ling 1972; Poelchau 1976; Bukry 1976a; McCartney 1988; Onodera \& Takahashi 2009), with specific terms introduced by these workers listed in the glossary at the end of this paper. Mathematical models of silicoflagellate skeletons (McCartney \& Loper 1989; Tsutsui et al. 2009) identify a need for terms for specific skeletal components and the locations where these connect. Further, studies of Cretaceous morphologies (McCartney et al. 2011, 2014a) and of double skeletons (McCartney et al. 2014b, 2015a) have expanded this terminology and demonstrate a need for more consistent application across disparate groups. Finally, a general study of silicoflagellate skeletal structure also shows an almost universal application of simple geometric rules (McCartney \& Loper 1989) which provide context for discussion of phylogenetic history and aberrant and unusual skeletal morphologies (McCartney \& Wise 1990).

The purpose of this paper is to propose a standard terminology to describe silicoflagellate skeletons, following a review of established and recently defined descriptive terms and present some new ones. All terms shown in boldface are included in the glossary and generally in the figures. For convenience and comparison of relative length and thickness of each structural component discussed here, Figures 1-4 provide scanning electron microscope (SEM) images at the same magnification (except Figs 3:5, 4:6 and 4:7). Emphasis in this paper is on major Cenozoic genera that have a dome-shaped (apical) structure attached to a basal ring. This is a companion paper to McCartney et al. (2014a) which describes Cretaceous silicoflagellate morphology.

\section{Orientation of the silicoflagellate skeleton}

Silicoflagellate skeletons may be depicted as a shallow inverted basket-like design. In this analogy, the rim of the basket would be the basal ring composed of a series of linear to curved elements, known as basal sides that connect to form a circular to elongate structure that often has a polygonal design. The basal corners of the polygon lie within a basal plane. The basket body, known as the apical structure, is formed of a system of elements that meet at triple junctions and compose a dome-shaped design whose apex is above the middle of the basal ring.

The terms apical and abapical (Fig. 1) are used by convention to orientate the skeleton, although these do not relate to orientation of the living organism (Moestrup \& Thomsen 1990). Apical view looks down on the top of the apical structure (i.e. towards the bottom of the basket) whereas abapical view (sometimes called basal view) looks through the basal ring into the basket. Lateral view is a perspective from the side, within the basal plane. Perspectives that are tilted with respect to each of these views are known as oblique apical view, oblique abapical view and oblique lateral view, 


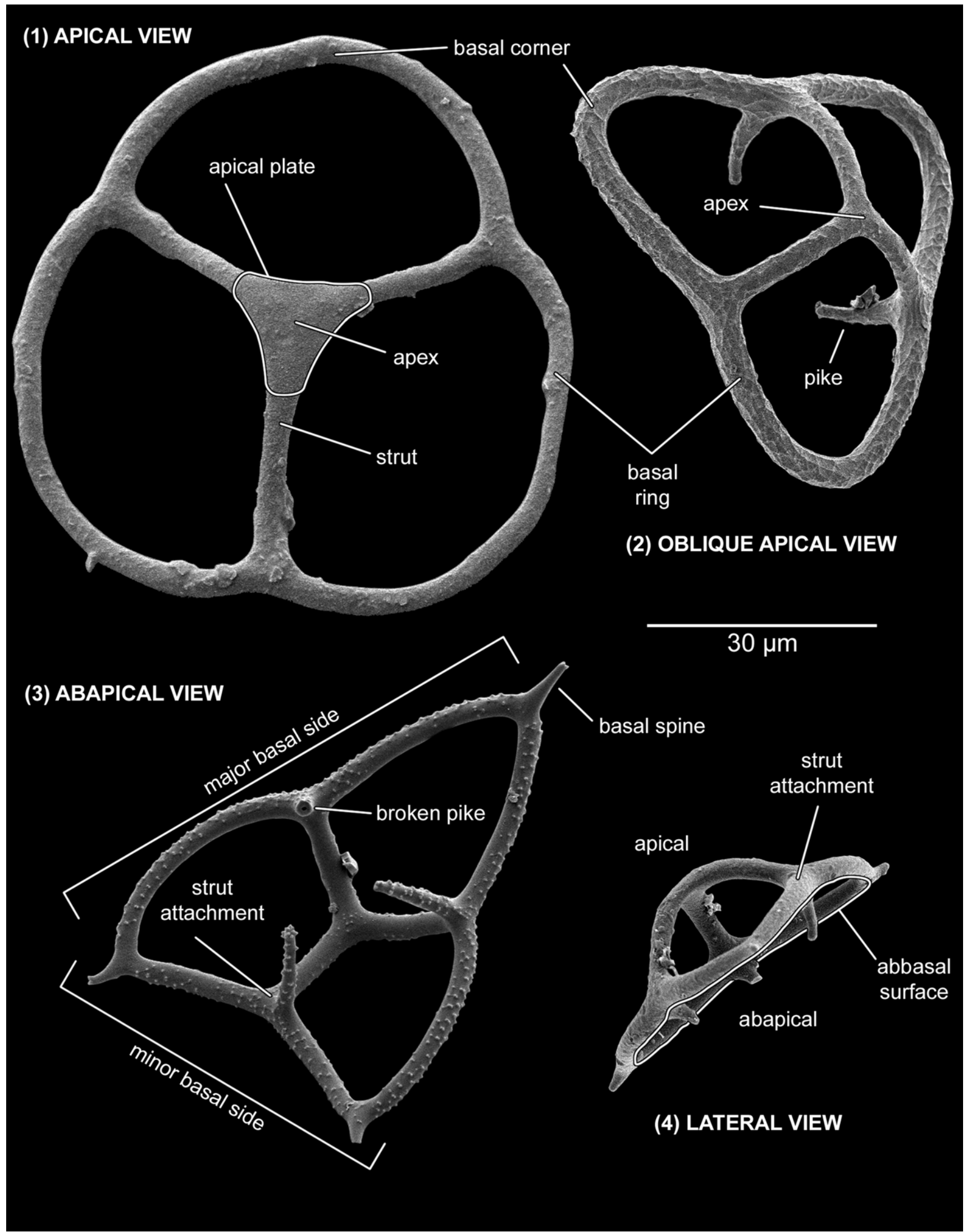

Fig. 1. SEM micrographs of Corbisema spp. to show skeleton orientation terminology. 1. Apical view, C. geometrica Hanna, Horton River, Northwest Territories, Canada, Late Cretaceous. 2. Oblique apical view, C. archangelskiana (Schulz) Frenguelli, Urals, Russia, Late Cretaceous. 3. Abapical view, C. hastata (Lemmermann) Bukry, Fur Formation, Mors, Denmark, early Eocene. 4. Lateral view, DSDP Site 275, Campbell Plateau, SW Pacific Ocean, Late Cretaceous.

respectively. The term abbasal is used to refer to locations beyond the basal ring and abbasal surface is used for the abapical underside of the ring (Fig. 1:4).
Double skeletons, also known as paired skeletons or doublets (Figs 2:1-2:3), are two skeletons that remain attached at the abbasal surfaces as part of silicoflagellate cellular division and 


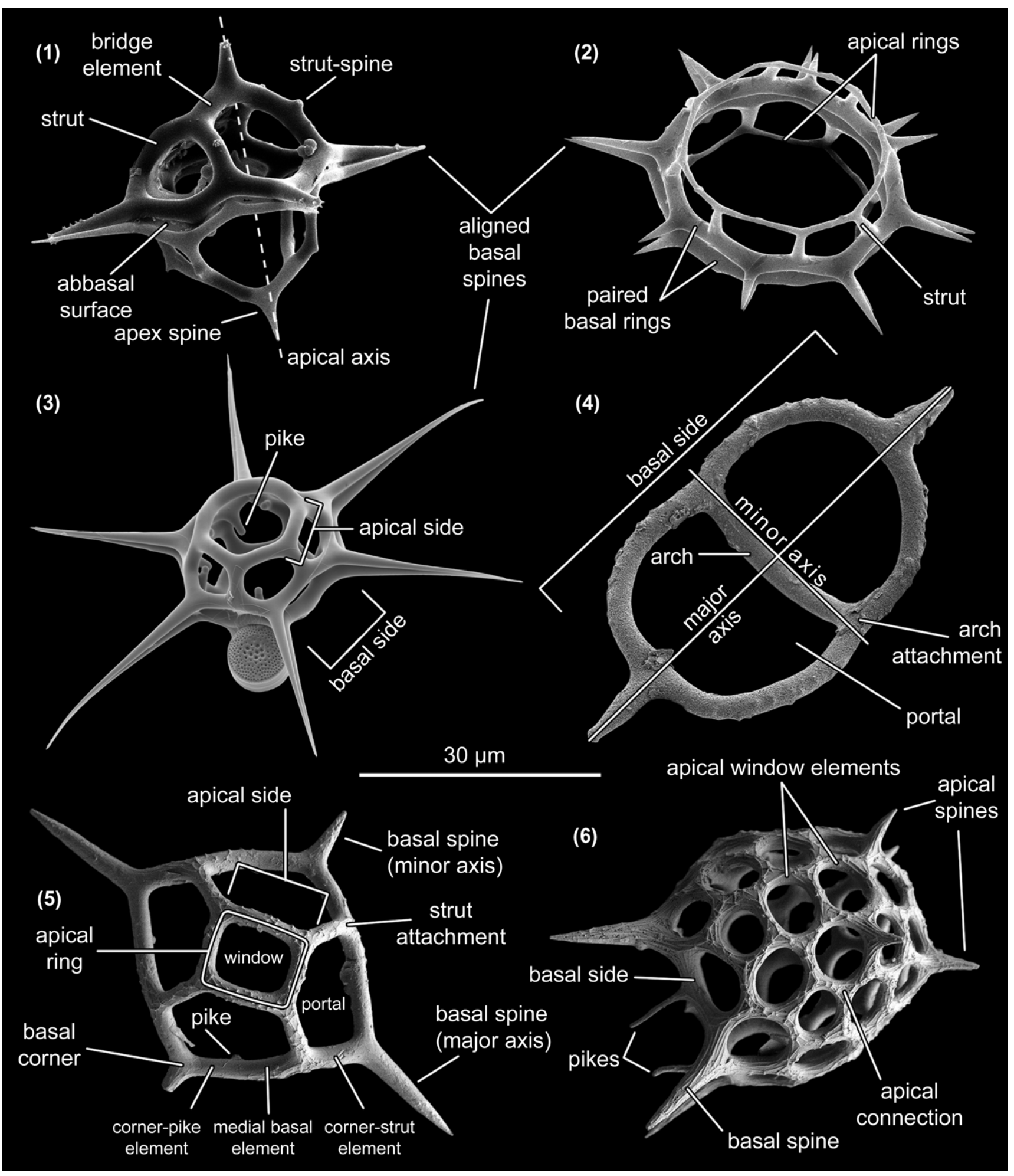

Fig. 2. SEM micrographs of double and single skeletons. 1. Double skeleton of Dictyocha stapedia Haeckel, Seto Inland Sea, Japan, Recent, lateral view. 2. Double skeleton of Octactis pulchra var. pulchra Schiller, Seto Inland Sea, Japan, Recent, oblique apical axis view. 3. Double skeleton of Stephanocha speculum (Ehrenberg) McCartney \& Jordan, Southern Ocean near Australia, Recent, oblique apical axis view. 4. Naviculopsis lata (Deflandre) Frenguelli, Hata Formation, Bōsō Peninsula, Japan, Miocene, abapical view. 5. Distephanopsis crux (Ehrenberg) Dumitrică, Tilvici Valley, Romania, middle Miocene, apical view. 6. Cannopilus sp., Tilvici Valley, Romania, middle Miocene, lateral view.

are important to the interpretation of single-skeleton structure (Dumitrica 2014; McCartney et al. 2014b, 2015a). The abbasal surface where paired skeletons attach may or may not be planar as some components of the basal sides can be angled slightly in an apical and abapical direction. The apical axis is a line perpendicular to the basal plane that runs through the centre of the apical structure and basal ring, and through the corresponding structures of the paired skeleton (Fig. 2:1). The intersection of this apical axis and the basal plane(s) is considered to be the centre of each individual skeleton and the dividing cell bearing a double skeleton. In most cases, the radial orientation of all spines is with respect to this central point. Since doublets have two skeletons, one often in apical and the other in abapical view, the term apical axis view is used, or, oblique apical axis 


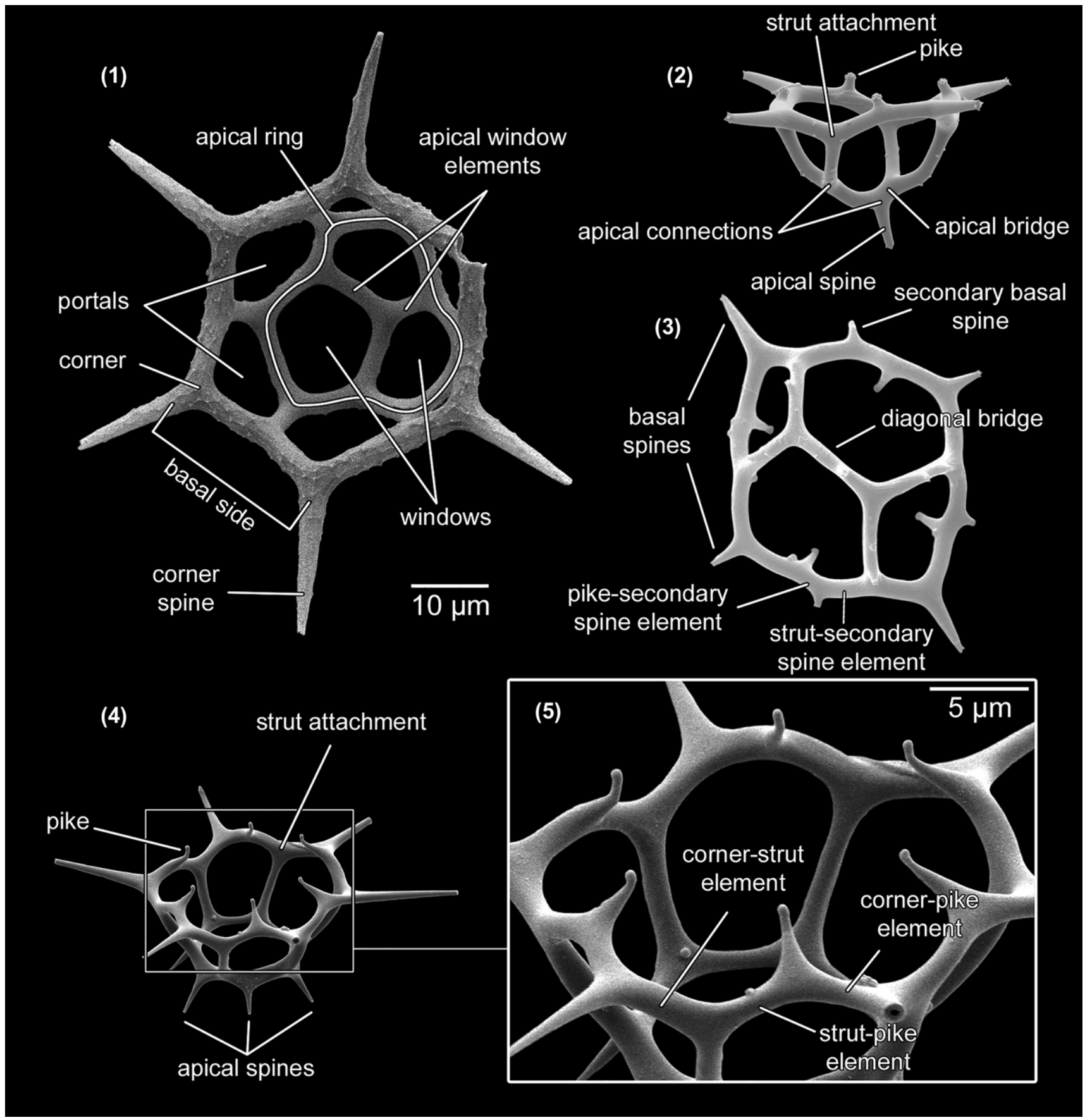

Fig. 3. SEM micrographs showing general terminology for Cenozoic silicoflagellates. 1. Stephanocha sp., Kamyshlov, Russia, early Eocene, abapical view. Note the absence of pikes on the underside of the basal ring. 2. Dictyocha sp., central Pacific Ocean near Hawaii, Recent, lateral view. 3. Dictyocha sp. cf. D. aculeata (Lemmermann) Bukry, Recent, apical view. 4, 5. Stephanocha speculum var. coronata (Schulz) McCartney \& Jordan, SW Pacific, Recent, oblique abapical view.

view where the specimen is somewhat tilted (see McCartney et al. 2014b, 2015a).

\section{General terminology}

Any integral rod- or plate-shaped piece of a silicoflagellate skeleton can be called a component. Rod-shaped components have an external thickness that is much less than the length. Essentially all silicoflagellate components are hollow over at least some portion of their extent. Rod-shaped components are of two basic descriptions: those that are connected at both ends, here termed elements, and those that are terminated distally. Elements form the basal and apical structures and are connected either to two additional elements or an element and a terminated component. Short elements tend to have linear or gently curved shapes, but longer elements may have a pronounced convex curve away from the centre of the basal plane (Fig. 2:4). Distally terminated components are known as spines or pikes, based on location and orientation. Spines most often occur at the corners of the basal ring (Fig. 1:3), known as corner spines, but apical spines may be present on the apical structure. Spines are nearly always linear, oriented radially with the distal end directed away from the cell centre and connected to two elements as part of a triple junction. Pikes differ from spines in shape, location and purpose. Flat to curved components known as plates (Fig. 1:1) occur occasionally on the apical structure.

While all silicoflagellate skeletal morphologies discussed in this paper have a basal ring, the term basal structure is also widely used. The basal structure has particular utility among Cretaceous 


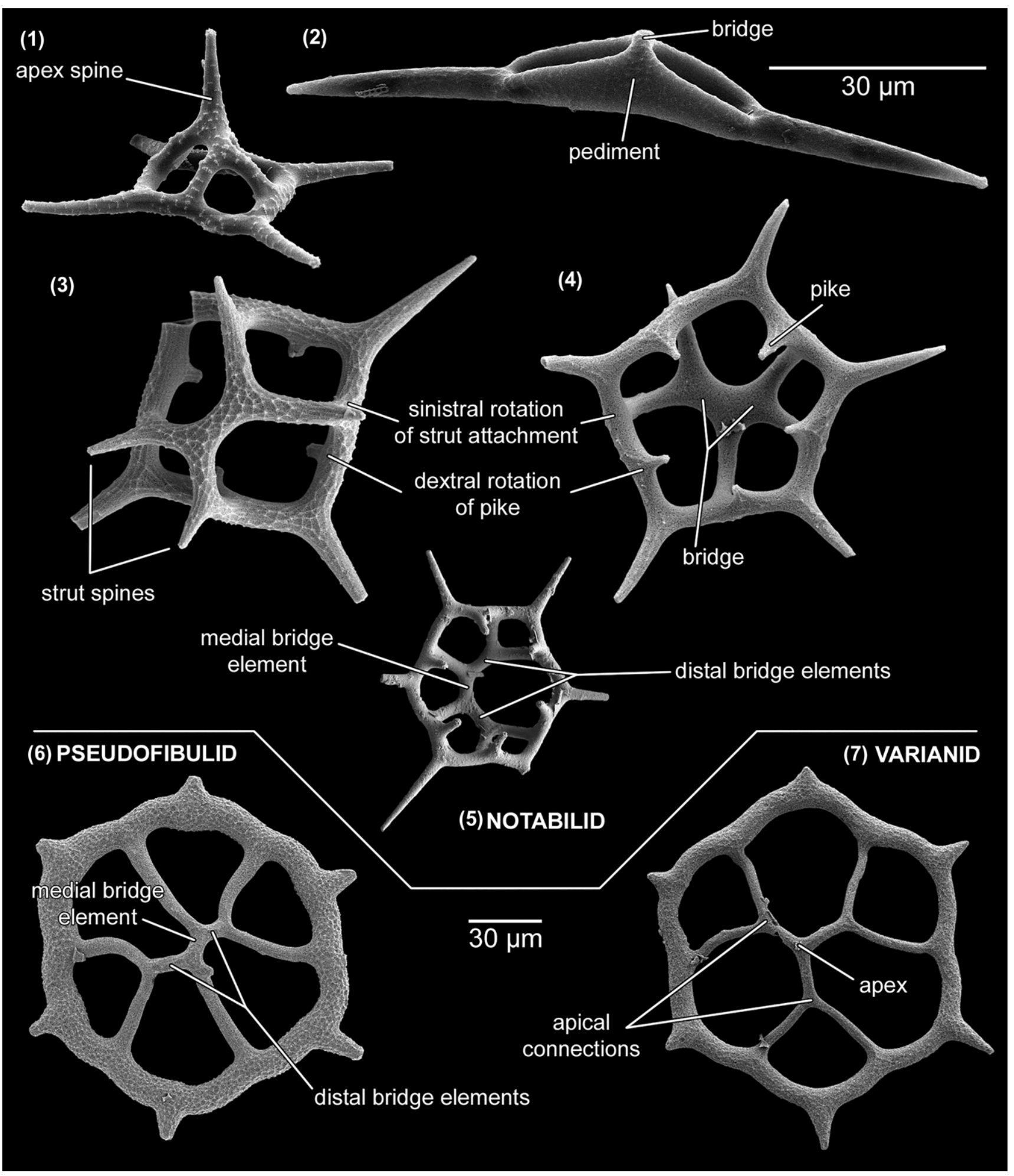

Fig. 4. SEM micrographs showing general terminology for Cenozoic silicoflagellates. 1. Dictyocha arctios Ling, Fur Formation, Mors, Denmark, early Eocene, oblique lateral view. 2. Naviculopsis constricta (Schulz) Frenguelli, Fur Formation, Mors, Denmark, early Eocene, oblique lateral view. 3. Dictyocha frenguellii Deflandre, Kamyshlov, Russia, early Eocene, apical view. 4. Dictyocha pentagona (Schulz) Bukry \& Foster, Kamyshlov, Russia, early Eocene, abapical view. 5. Stephanocha speculum var. notabilis (Gran \& Braarud) McCartney \& Jordan, ODP Site 693, Weddell Sea, Miocene, abapical view. 6. Dictyocha grandis Ciesielski \& Shaw, pseudofibulid morphotype, ODP Site 748, Southern Kerguelen Plateau, Southern Ocean, middle Eocene, apical view. 7. Dictyocha grandis Ciesielski \& Shaw, varianid morphotype, ODP Site 748, Southern Kerguelen Plateau, Southern Ocean, middle Eocene, abapical view.

morphologies that lack a ring design, and is sometimes used here where the application is also to non-ringed morphologies (McCartney et al. 2014a). These evolutionarily primitive morphologies include terminated components - segments, sabatons and pike-and-spines - that are not observed in the Cenozoic, except on aberrant or teratoid specimens (Guex 2006). Some Cretaceous morphologies require other terms, such as 'limb', that are not used in regard to Cenozoic silicoflagellates and thus not further discussed in this paper. The general rules and terminology reviewed and presented here, however, also apply to the Cretaceous forms.

The basal ring usually has a polygonal shape that can be elongated with a major axis and minor axis. The term diameter is 
applied to the size of the basal or apical ring, measured across opposite corners (we measure across the triple-junction midpoints). Between adjacent basal corners is a basal side composed of a series of one or more elements that includes a single location where the apical structure attaches to the basal ring. Thus, the basal sides of all silicoflagellate skeletons that have a basal ring and apical structure have at least two elements, separated by an attachment. All other locations where skeletal components adjoin are known as connections.

For silicoflagellate skeletons with three or more basal sides, the apical element that attaches to the basal ring and supports any additional elements or spines that compose the apical structure is known as the strut, with the location where the apical and basal structure adjoin being the strut attachment. The number of basal sides, corners and struts are equivalent except for unusual morphologies. Apical structures exhibit a wide range of designs, from simple (Fig. 1:2 and 2:4) to more complicated (Figs 2:5 and 2:6).

\section{Descriptive terminology}

\section{Skeletal taxonomy}

Silicoflagellate taxonomy at both genus and species level is based on skeletal morphology, particularly the number of basal sides and complexity of the apical structure. Simple geometries divide the silicoflagellates into separate morphogroups that are interpreted as distinct genera. Nevertheless, taxonomic interpretation varies considerably, particularly among biologists who recognize as few as one, or as many as three, extant genera (e.g. Moestrup \& Thomsen 1990; Martínez-López et al. 2012). While naked silicoflagellates have been described, such as Vicicitus of Chang et al. (2012), it is uncertain whether this and other taxa lack a skeleton throughout their life cycle, which, although incompletely understood, is known to include multiple naked and skeletonbearing stages (Henriksen et al. 1993; Chang 2015).

In the Cenozoic, there are six diverse genera with long geological histories, listed here in the order of appearance in the stratigraphic record: three-sided Corbisema Hanna (Figs 1:1-1:4), elongate Naviculopsis Frenguelli (Figs 2:4 and 4:2), apically bridged Dictyocha Ehrenberg (Figs 2:1, 3:2, 3:3, 4:1, 4:3, 4:4, 4:6 and 4:7), apically ringed Distephanopsis Dumitrică with four basal and apical sides (Fig. 2:5), apically ringed Stephanocha McCartney \& Jordan with more than four sides (Figs 2:3, 3:1, 3:4 and 3:5) and Cannopilus Haeckel (Fig. 2:6) with complicated apical structures of more spherical shape. There are cases in which a skeletal morphology has the general appearance of one genus but actually belongs in another; an example is a group of bridged morphologies associated with Stephanocha speculum (Ehrenberg) McCartney \& Jordan (Fig. 4:5). Not figured in this paper are skeletal morphologies that consist of a basal ring without apical structure that are commonly grouped into Bachmannocena Locker (see Bukry 1987: synonyms for this genus include Mesocena Ehrenberg, Paradictyocha Frenguelli and Septamesocena Bachmann). Of the Cenozoic genera listed above, only Corbisema occurs also in the Cretaceous.

Minor Cenozoic genera include Crassicorbisema Ling, Deflandryocha Jerković, Eunaviculopsis Ling, Hannaites Mandra, Neonaviculopsis Locker \& Martini and Octactis Schiller. These occur over shorter stratigraphic intervals, have uncertain taxonomic uniqueness and, except for the eight-sided Octactis (Fig. 2:2), are not discussed in this paper, although the morphological terms presented here also apply to these genera.

\section{Rules of silicoflagellate skeletal design}

The structural design of silicoflagellate skeletons abides by a simple set of 'rules' (McCartney \& Loper 1989; McCartney \& Wise 1990).
These are summarized as follows and will be applied in the following sections

(1) Skeletal components connect at triple junctions, with apical angles generally close to $120^{\circ}$.

(2) The basal ring has thicker elements than those of the apical structure and a radial, rotational or bilateral symmetry.

(3) One strut occurs for each basal side and the numbers of strut attachments, sides and corners are equivalent.

(4) Basal and apical rings are complete and have the same number of sides, with the planes of both rings being parallel.

(5) Any curvature of elements is away from the middle of the cell.

(6) Spines are oriented radially away from the middle of the cell.

(7) Spine lengths are proportional to major and minor axes of the basal ring and often proportional to the acuteness of the angle between the two adjoining elements.

(8) Completely formed members of a double-skeleton pair have essentially identical features, which would include any rotation of the apical structure in relation to the basal structure.

Silicoflagellate skeletons that violate any of the above rules are generally considered to be teratoid specimens. Due to their extraordinary variability, aberrant silicoflagellate skeletons are not discussed here in the context of terminology (but see McCartney \& Wise 1990). However, since the occurrences of aberrant morphologies may be of high significance in palaeoenvironmental reconstructions, we recommend that the number of aberrant specimens be included in formal counts (e.g. McCartney \& Harwood 1992; Tsutsui \& Takahashi 2009).

\section{The basal ring}

The basal ring occurs on all normal (i.e. non-teratoid) Cenozoic silicoflagellate skeletons, and has a polygonal to near-polygonal design with corners and sides that surround an open region known as the basal window. The basal plane is defined as including the basal corners, but other components of the basal sides are proximal to this. Seen from apical view, the sides can be linear or bowed convexly away from the cell centre and may be inflected inwards at the strut attachments (Figs 1:1-1:3). From lateral view, strut attachments are slightly above (i.e. in apical direction, see Fig. 1:4) and pikes slightly below (i.e. in abapical direction, Fig. 3:5) the basal plane. Corner spines are usually present and lie within or near the basal plane. Spines may not be present where basal corners are well rounded as occurs with some Cretaceous and Palaeogene Corbisema (Figs 1:1 and 1:2). In general, corner and other spines are longer when the angle between the two connecting elements is more acute.

Pikes are curved, trend in an abbasal direction and usually point towards the apical axis (Figs 1:2-1:4). The pike location on the basal side appears to be independent of the rule of triple junctions, as pikes may occur on the abbasal surface immediately beneath the strut attachment (Fig. 1:2). A recent paper (McCartney et al. 2015b) offers a terminology for diverse pike morphologies in the Eocene. Pikes appear to serve some function in holding paired skeletons together (Moestrup \& Thomsen 1990) and, for some species, may support the outer cell boundary of the paired skeleton (McCartney et al. 2015a). However, some species of Corbisema, Dictyocha, Distephanopsis and Stephanocha - and all non-aberrant Naviculopsis and Octactis - lack pikes (Figs 1:1, 2:2, 2:4, 3:1, $4: 1,4: 2,4: 6$ and $4: 7)$.

The location of the strut attachments and associated apical structure may be rotated towards a set of basal corners. The direction of rotation is presented in relation to apical view, looking down the apical axis, unless otherwise noted. While Palaeogene silicoflagellates often have strut attachments and pikes in close proximity, 
Neogene Dictyocha, Distephanopsis and Stephanocha often have strut attachments rotated towards the sinistral corner, whereas the pike is closer to the dextral corner (Figs 2:1, 2:5, 3:3-3:5, 4:3-4:5). Due to this rotation, the perceived skeletal design can differ according to direction of perspective (see Figs 2:1, 2:3, 2:5, 3:2-3:5 and $4: 3-4: 5$ ), so apical, abapical or lateral view need to be specified for all specimens.

Where the strut attachment and pike do not occur in close proximity, the separation creates a third basal element that, together with the elements that connect to the corners, can cause the basal side to take a pronounced zig-zag shape in lateral view (Figs 2:1, 3:4 and 3:5), as elements undulate apically towards the strut attachment and abapically towards the pike. We identify the basal elements that connect to the corners as the corner elements, or when reference to a specific portion of the basal side is required, the corner-strut element and corner-pike element, with the element between these being the medial basal element (Fig. 2:5). The rotated apical structure does not occur on modern Octactis (Fig. 2:2) and in various fossil specimens (e.g. Fig. 3:1), particularly where there are no pikes.

Fossil specimens of Corbisema, Naviculopsis and some Dictyocha have basal elements that curve away from the centre of the basal ring, but modern species tend to have more linear elements, with flexure of the basal sides accommodated by angular junctures where basal elements adjoin the struts and pikes (Figs 2:1, $3: 2,3: 5$ and 4:5). For some morphologies, such as the Pleistocene Dictyocha aculeata (Lemmermann) Dumitrică (Fig. 3:3), a portion of the basal side may be divided by a triple junction that includes a secondary spine, which can break the basal side into four elements. The secondary spine between the strut and pike junctures establishes the strut-secondary spine element and pike-secondary spine element (Fig. 3:3). For Eocene Corbisema hexacantha (Schulz) Perch-Nielsen and Miocene Distephanopsis stauracantha (Ehrenberg) Dumitrică, the secondary spines may be of lengths equivalent to corner spines.

The basal sides are usually of equivalent lengths, with the angles at the basal corners also being equivalent. Thus, the basal rings of many Corbisema species have an isosceles shape; however, C. hastata (Lemmermann) Frenguelli and other species have two longer major basal sides and a short minor basal side (Fig. 1:3). The minor axis corner spines are in some subspecies not oriented radially, and rare doublets show each skeleton to be flipped $180^{\circ}$ with respect to the other (McCartney et al. 2015c).

\section{The apical structure}

The apical structure comprises a system of skeletal elements that construct a dome-shaped latticework of triple junctions. The interconnected elements enclose openings in the latticework known as portals when these abut the basal ring and windows when they are surrounded by apical elements (Fig. 3:1). The triple junctions formed by these elements have angles that are more equivalent, and generally near $120^{\circ}$, where the thickness of the components is equivalent near the juncture (e.g. Fig. 3:1). The angles are less equivalent when the thicknesses are unequal, as often occurs where the strut and pikes adjoin the basal ring (Figs 2:5, 3:1 and $3: 3$ ).

The simplest apical structure is the arch-shaped component that extends across the minor axis of the spindle-shaped Naviculopsis (Figs 2:4 and 4:2). There has, however, not been any detailed morphological study of the group and we find the term most often applied to this structure, the band (Bukry 1976a), to inadequately communicate the range of common morphologies. We suggest the new term arch for a thin element that connects across the minor axis, with the juncture of the arch and basal ring being the arch attachment (Fig. 2:4). We use the term pediment for a broad base that supports an arch (Fig. 4:2). The term band would be applied to a curved plate that is more expanded along the major axis, such as occurs with $N$. constricta (Schulz), $N$. foliacea Deflandre or N. nordica Bukry (see Bukry 1976b, pl. 2; McCartney \& Wise 1987, pl. 5; Ciesielski 1991, pls 9, 10). The midpoint of the arch, which is also the highest point above the basal plane, is the apex. An apex spine occurs on some Naviculopsis species, with an extreme example being $N$. trispinosa (Schulz) (see Perch-Nielsen 1975, pl. 13), which has an apex spine of length equivalent to the corner spines. It is worth noting that Naviculopsis includes a wide range of unusual apical structures (e.g. Ciesielski 1991).

Corbisema, Dictyocha, Distephanopsis, Stephanocha and Cannopilus consistently have struts that attach to the basal ring and on the apical ends can either: (1) meet at an apex (Corbisema), (2) meet to support a bridge (typically, Dictyocha), (3) meet two elements that are part of an apical ring (Distephanopsis, most Stephanocha) or (4) form a more complicated structure (Cannopilus). Of these, the three-sided Corbisema has the simplest apical structure as the three struts meet at an apex that does not include a spine, although there may be an apical plate (Fig. 1:1). A bridge is a series of one or more apical elements that connect the struts and extend across the central region of the skeleton. Among the four-sided Dictyocha, the bridge has a linear shape when observed from apical view that is always located immediately above the centre of the basal plane. From lateral view the bridge may take the shape of a single, rather flat-lying element, or can consist of two elements that are inclined apically to meet at an apex where an apex spine completes a triple junction (Fig. 4:1). A spine can also occur on the strut, known as a strut spine (Fig. 4:3), although such spines are unusual. The basal ring often has a rhomb-shape in apical view, with a major and minor axis, and the bridge can have various orientations, as will be presented below. For five-sided morphologies, two bridge elements often form a triple junction with a strut (Fig. 4:4). There is a particularly wide range of bridge morphologies that can include considerable variation within a species, among silicoflagellates that have more than five basal sides.

The terms 'asperid' and 'fibulid' have been applied to describe the orientation of the bridge of four-sided Dictyocha, but have become ambiguous and should no longer be used. Asperid (named after $D$. aspera Lemmermann), as originally used, has a bridge aligned with the basal ring minor axis. Fibulid (named after D. fibula Ehrenberg), as originally used, has a bridge aligned with the basal ring major axis. 'Aculeatid' (named after D. aculeata Lemmermann) has been used for bridges diagonal to both axes (Fig. 3:3). However, based on a study of Ehrenberg materials, Locker (1974) assigned an asperid lectotype to D. fibula. Some workers have followed this change (e.g. Locker \& Martini 1986; McCartney et al. 1995), while others have not. Also, there is no consistent use of $D$. aculeata as some workers use $D$. mandrai Ling for what may be the same species. For four-sided Dictyocha with bridges parallel to the minor, major or diagonal to both axes, we suggest descriptive reference to minor-axis-bridged, major-axisbridged and diagonally-bridged morphologies.

Variant apical bridges are also known. For six-sided varieties of Stephanocha speculum that make up the late Miocene pseudofibula plexus (McCartney \& Wise 1990), bridges can consist of three elements. These morphologies, which we now refer to as 'plexids', are also commonly observed for Dictyocha grandis in the middle Eocene (Witkowski et al. 2012) and occur elsewhere as well. The three distinct morphotypes 'pseudofibulid', 'notabilid' and 'varianid' (Figs 4:5-4:7) make up most of the plexid variability. The bridge of the pseudofibulid morphotype has a series of three elements of which the middle element, here termed the medial bridge element, goes over the mid-point of the basal ring and is thus on the apical axis with the connecting struts attaching to opposite sides of the basal ring (Fig. 4:6). Notabilid morphotypes (Fig. 4:5) 
have the medial bridge element not centred over the middle of the basal plane and connecting struts attach to adjacent sides (Fig. 4:5). The varianid morphotype has three bridge elements that meet at an apex (Fig. 4:7) immediately above the centre of the basal ring and is the only apical structure that includes a triple junction made exclusively of bridge elements.

Species of Distephanopsis, Octactis and Stephanocha are generally characterized by a series of elements that form an apical ring. The ring has a polygonal shape similar to the basal ring that is made of apical sides that meet at apical corners. The corners lie within an apical plane that is parallel to the basal plane. An apical side can have a single apical ring element or two elements that form a triple junction with an apical spine. For most Distephanopsis and Stephanocha, the elements that compose the apical structure are of generally equivalent thicknesses and the struts are inclined towards the apical axis to support an apical ring that is smaller than the basal. Octactis has an unusual skeletal morphology in which the struts are nearly perpendicular to the basal plane, and have a thickness that decreases towards the apical ring, which is thus of relatively large diameter but made of thin elements.

The terminology presented thus far for elements of the apical structure includes struts and those elements that compose the bridge or apical ring. Some Stephanocha morphologies have an apical ring that is subdivided into two or more windows; this group is commonly called 'cannopilid' (Fig. 3:1, see also Bachmann 1970, pls 6, 7; McCartney \& Wise 1990, pl. 4). To accommodate these more complicated apical structures, elements that subdivide the apical structure into multiple windows are here presented as apical window elements. We offer no more specialized terminology for these elements, but for subdivided apical rings on Stephanocha, the terms 'apex' and 'bridge' can be used; the term 'strut' cannot be used as this applies exclusively to elements that attach to the basal structure.

Cannopilus (Fig. 2:6; also called Caryocha, see Bukry \& Monechi 1985) has a considerably more complex apical structure composed of many elements. The overall shape of the skeleton is often more spheroidal, with an apical diameter than can be larger than that of the basal ring. Unlike multi-windowed skeletons of Stephanocha (see Bachmann 1970, pls 6, 7; McCartney \& Wise 1990, pl. 4), Cannopilus does not have a system of elements that form a distinct apical ring; instead there is a single ring of portals adjacent to the basal ring, and numerous, often undifferentiated windows in the apical structure (Fig. 2:6). Here, all elements that compose the apical structure except the struts can be identified as apical window elements.

\section{Double skeletons}

Recent work on double skeletons (McCartney et al. 2014b, 2015a) identified the need for additional terminology. Double skeletons develop sequentially and thus consist of a mother and daughter skeleton. While these are oftentimes indistinguishable, in some cases one skeleton has thicker elements or basal spines and is interpreted as being the older (mother). For the Dictyocha double skeleton illustrated here (Fig. 2:1), the skeleton with thicker skeletal elements (top part of illustration) may be interpreted as the mother and the lower skeleton as the daughter. While the terms 'sibling' (McCartney et al. 2014b) and 'partner' (Boney 1981) have been previously used, we now recommend reference to the paired skeleton where the mother and daughter cannot be interpreted.

Fossil double skeletons with basal rings are now known to occur in two distinct configurations. Skeletons that have basal rings of similar orientations that are more or less connected at the corners, which includes all modern silicoflagellates, are referred to as the corner-aligned configuration (McCartney et al. 2014b; Figs 2:12:3). In contrast, the Star-of-David configuration (McCartney et al.
2010) has the basal corners of each skeleton rotated to be midway between the corners of the paired skeleton and represents a group of silicoflagellates that is believed to have become extinct in the Oligocene (McCartney et al. 2015a).

\section{Discussion}

The past few years witnessed a considerable revival in silicoflagellate studies: a wealth of new data from fossil deposits of various ages has been made available (McCartney et al. 2011, 2014a; Witkowski et al. 2012) and long-standing taxonomic issues have been successfully resolved (Jordan \& McCartney 2015). New insights have provided improved understanding into the cell structure and biology of modern silicoflagellates and closely related taxa (Chang et al. 2012; Chang 2015) and double skeletons (McCartney et al. 2010, 2014b, 2015a, c; Dumitrica 2014; Abe et al. 2015). Even a superficial reading of this new literature demonstrates the need for a consistent and updated terminology for the description of silicoflagellate skeletons, which can be applied to both fossil and living taxa.

The purpose of this work is to review the existing silicoflagellate descriptive terminology, make the necessary amendments and propose new terms either for specific elements previously not identified, or that we found were dealt with in a manner that lacked precision. Any terminology needs to be communicative, which in turn is a compromise between the level of detail and utility. We see no point in attempting to name every single component of a silicoflagellate skeleton. Especially in the extremely complex morphologies, such as the cannopilids, terms could be multiplied ad infinitum; the utility of such terms, however, would be limited.

Whether the terminology reviewed and put forward here becomes successful will need to be verified by future studies; we realize some of the terms proposed here, especially the very specialized ones differentiating the basal ring into elements located between struts and pike attachments, etc., will likely remain restricted to highly specialized studies, e.g. mathematical modelling of silicoflagellate skeletons. It is our sincere hope, however, that these propositions will be worked upon and added to, and in the long perspective will help to improve the sometimes deficient communication between scientists working with silicoflagellates.

\section{Glossary}

The original source of a term is listed unless there is a wellestablished convention; synonymous terms are also provided.

\footnotetext{
Abapical (Marshall 1934, also known as basal): In a direction away from the apex and towards the basal ring. Abapical view is the point of perspective that has the basal structure nearest and the apex furthest from the observer.
}

Abbasal (McCartney et al. 2014b): In the portion of the basal structure furthest from the apex. The abbasal surface, for example, occurs at the points of connection or between members of a paired skeleton. Also, in a direction or region abapical of the basal ring. Apex (McCartney 1988): The point on an element or connection of elements that is located directly above the middle of and furthest from the basal plane. Two elements may connect with an apex spine at this location.

Apex spine (McCartney et al. 2014b): A spine that occurs at the apex of the apical structure, and is usually aligned with the apical axis. Synonymous terms include 'accessory spine' (Gleser 1966) and 'spire' (Bukry 1976a).

Apical: Related to a system of elements that form a dome-shaped framework known as the apical structure that is attached to the basal ring. Also, in the direction towards the apex, which is the point 
on the skeleton furthest from the basal plane. Apical view is the point of perspective that has the apex nearest the observer.

Apical axis (McCartney et al. 2014a, b): An imaginary line that goes through the middle of both members of a double skeleton, and is perpendicular to the basal plane. Apical axis view is the point of perspective that has the two members of a double skeleton, one in apical and the other in abapical view.

Apical ring: System of elements that form a ring and are attached to the basal ring by struts. Associated terms include apical side, apical corner, apical plane, apical ring element and apical ring spine. Apical window elements (this paper): Elements that abapically connect to the apical ring. Synonymous term is 'Apikalstäbe' (Gemeinhardt 1930). These may meet at an apex, support a bridge or form a complicated design with many windows.

Arch (this paper): An element that extends across the minor axis of the basal ring in Naviculopsis. The apex of the arch is above the middle of the basal plane. The arch is equivalent to the strut of other basal-ringed skeletons, but extends across the minor axis corners without required additional apical elements or a triple junction.

Arch attachment (this paper): The location where the Naviculopsis arch adjoins the basal ring.

Attach/attachment (McCartney 1988): Applies to the location where the apical and basal structures adjoin (e.g. strut attachment or arch attachment).

Band (Bukry 1976a): A curved plate that extends across the minor axis of Naviculopsis, having an apex that is expanded in the major axis direction to be significantly wider than the basal elements. Synonymous term is 'apical plate' (Gleser 1966).

Basal: Related to a system of skeletal components that are furthest from the apex, and part of the basal ring or basal structure. Also, a synonym for abapical, that shows direction or view away from the apex.

Basal corner: Sharp angle or change in curvature that separates a system of elements that make up the side of the basal ring. The basal corner is often a junction of two basal ring elements and a corner spine.

Basal plane (McCartney et al. 2014b): Plane that connects the corners of the basal ring.

Basal ring: System of elements that form a ring, to which the apical structure is attached, and that provides the surface to which a similar ring of a paired skeleton may be joined. Also known as the basal structure.

Basal side: System of one or more elements on the basal ring that connect the basal corners. Synonymous terms include 'basal rod' (Gleser 1966) and 'Basalbögen' (Stradner 1961). The elements that connect between the corners, struts, pikes, secondary spines and arch can be individually identified as the corner-strut element, corner-pike element, medial basal element, pike-secondary spine element, strut-secondary spine element and corner-arch element (all terms from this paper). In the case of a 'hastatid' Corbisema skeleton (Fig. 1:3) the basal sides can be differentiated as a minor basal side (shorter) and two major basal sides (longer). Basal window (Gleser 1966): The region within the basal ring that lacks skeletal components.

Bridge (Poelchau 1976): Apical element or series of elements that abapically connects to other apical elements and extends across the apex region of the skeleton. Most typically supported by struts but the term can be applied to elements that connect across an apical ring. Synonymous terms include 'Diagonaler' (Gemeinhardt 1930), 'central arch' (Marshall 1934), 'apical rod' (Gleser 1966), 'apical bar' (Ling 1972) and 'bar' (Bukry 1976a). The bridge can have major-axis-, minor-axis- or diagonally-bridged alignments (all terms, this paper).

Component (McCartney et al. 2014a): Any integral portion of the silicoflagellate skeleton, connected to other components.
Connect/connection: Applies to the location where skeletal components of the apical or basal structures adjoin. Locations between apical and basal structures are termed attachments.

Corner: See apical corner, basal corner.

Corner element (this paper): Any element that connects to the corner of a basal or apical ring. The corner-pike element and corner-strut element are associated with the pike and strut, respectively.

Diameter: Distance across the apical or basal ring, usually measured across the triple-junction midpoints of the major and/or minor axis. Double skeleton (also known as a doublet or paired skeleton): Two skeletons connected at the abbasal surfaces, in a position prior to cellular division. The first formed skeleton, if this can be interpreted, is the mother and the second, the daughter. Each is the paired skeleton of the other.

Element (McCartney et al. 2014a): A component between two triple junctions that makes up a portion of the basal or apical structure.

Lateral view: Perspective where the observer is positioned on or near the basal plane.

Major axis: Where the basal ring has an elongated shape, the line that connects the two opposite basal corners that are furthest apart. For Corbisema and other morphologies with an odd number of sides, the longest line that connects a basal corner with the midpoint of an opposite basal side.

Major basal side: For an elongated Corbisema basal ring, one of two sides that connect with the major axis. Term can also be applied to any of the four sides that connect to the major axis of Stephanocha.

Medial basal element (this paper): The element that is bounded by the locations where the pike and strut adjoin the basal ring.

Minor axis: The line that connects opposite basal corners that are separated by a shorter distance than those that determine the major axis. For Naviculopsis, Distephanopsis and four-sided Dictyocha, the minor axis is perpendicular to the major axis. For six-sided Stephanocha, there are two minor axes, each located at about $60^{\circ}$ relative to the major axis.

Minor basal side: For Corbisema and other odd-sided morphologies, the short basal side that is perpendicular to the major axis. Can also be applied to any of the sides associated with the minor axis of six- and eight-sided morphologies.

Oblique apical view or oblique abapical view: Perspective with the apical or basal structure nearer to the observer, respectively, but the apex not being the nearest or furthest. Oblique apical axis view is applied to a doublet that is tilted less than $45^{\circ}$ with respect to the observer.

Oblique lateral view: Perspective where the basal plane is inclined and elements of the basal ring are nearer than the apex to the observer.

Pediment (this paper): An arch attachment that is expanded near the basal ring (Fig. 4:2).

Pike (Bukry 1976a): Terminated component that points in general direction of paired skeleton of a doublet. Located on abbasal surface of basal element. Synonymous terms include 'centripetal tooth' (Haeckel 1887), 'Stützstachel' (Lemmermann 1908), 'subordinate radial spine' (Poelchau 1976) and 'basal accessory spine' (Ling 1972).

Plate (Mandra 1968): Broad continuous surface at the apex; occurs on silicoflagellate skeletons from the Late Cretaceous to Eocene.

Portal (Bukry 1976a): The space between the basal ring and elements of the apical structure, bounded in part by basal elements and struts. Synonymous terms include 'Basalfenster' (Lemmermann 1908) and 'lateral window' (Ling 1972).

Secondary spine (this paper): Spine that occurs along a basal side (Fig. 3:3), usually between the strut attachment and major axis corner and associated with morphologies that have considerable 
rotation of the apical structure (Dictyocha aculeata Lemmermann, Distephanopsis stauracantha (Ehrenberg) Dumitrică). Synonymous term is 'subordinate radial spine' (Poelchau 1976).

Spine: Terminated component that is usually oriented radially with respect to the centre of the basal plane. Spines are often identified by location such as the corner (basal) spine, apical spine, strut spine, apical ring spine or apex spine. Synonymous terms for corner spine include 'radial Stachel' (Lemmermann 1908) and 'radial horn' (Deflandre 1950); for apical spine synonymous terms include 'accessory spine' (Gleser 1966) and 'apical pike' (Bukry 1976a); for apex spine a synonym is 'spire' (Bukry 1976a).

Strut (Bukry 1976a): Element that joins the apical structure to the basal structure, at strut attachment (McCartney 1988). Synonymous terms include 'Basalstäbe' (Lemmermann 1908), 'supporting bar' (Marshall 1934) and 'lateral rod' (Gleser 1966). The strut can include a strut spine (Onodera \& Takahashi 2009).

Strut attachment (McCartney 1988): Juncture of a strut to the basal structure.

Thickness: The external diameter of a skeletal component. For an apical plate, the thickness would be measured in the direction of the centre of the basal plane.

Window (Lemmermann 1908, as 'Apicalfenster'): Opening in the apical structure bounded by apical elements, or subdivided portions, but not in contact with the basal ring. Synonymous term is 'apical opening' (Bukry 1976a).

\section{Acknowledgements and Funding}

Several SEM micrographs used in this paper were provided by colleagues: Kenta Abe and Richard Jordan at Yamagata University (Figs 2:1, 2:2, 4:1 and 4:2), Elisa Malinverno at University of Milano-Bicocca (Fig. 3:3) and Jeremy R. Young at University College London (Figs 2:3 and 3:2). David Harwood, Paulian Dumitrică, Patricia A. Sims and the Integrated Ocean Drilling Program provided samples that were the source of specimens illustrated in this study. SEM work at the Technical University of Warsaw was made possible by Krzytof J. Kurzydłowski, Andrzej Witkowski and Izabela Zgłobicka. Additional SEM work was provided by Manfred Ruppel, Johann-Wolfgang-Goethe Universität, Frankfurt am Main, Germany. The manuscript was reviewed by David Harwood and Andreś Rigual-Herdández, who provided many useful comments. This work was supported by a Trustees Professorship award from the University of Maine System, and by continued support from the University of Maine at Presque Isle. Laboratory, office and other resources were provided by the University of Szczecin, Palaeoceanography, and Geology and Palaeogeography Units.

\section{Scientific editing by Alan Lord}

\section{References}

Abe, K., McCartney, K., Fukunaga, Y., Narita, H. \& Jordan, R.W. 2015. Observations on silicoflagellates and ebridians from the Seto Inland Sea, including the description of Octactis pulchra var. takahashii var. nov. Journal of Nannoplankton Research, 35, 111-128.

Bachmann, A. 1970. Silicoflagellaten aus dem oberösterreichischen Egerien (Oberoligozän). Verhandlungen der Geologischen Bundesanstalt, 2, 275-305.

Boney, A.D. 1981. Distephanus speculum: double skeletons with one aberrant partner. Journal of the Marine Biological Association of the United Kingdom, 56, 1027-1029.

Bukry, D. 1976a. Silicoflagellate and coccolith stratigraphy, southeastern Pacific Ocean, Deep Sea Drilling Project Leg 34. In: Yeats, R.S., Hart, S.R. et al. (eds) Initial Reports of the Deep Sea Drilling Project, 34. US Government Printing Office, Washington, DC, 715-735.

Bukry, D. 1976b. Silicoflagellate and coccolith stratigraphy, NorwegianGreenland Sea, Deep Sea Drilling Project Leg 38. In: Talwani, M., Udintsev, G. et al. (eds) Initial Reports of the Deep Sea Drilling Project, 38. US Government Printing Office, Washington, DC, 843-855.

Bukry, D. 1987. Eocene siliceous and calcareous phytoplankton, Deep Sea Drilling Project Leg 95. In: Poag, C.W., Watts, A.B. et al. (eds) Initial Reports of the Deep Sea Drilling Project, 95. US Government Printing Office, Washington, DC, 395-415.

Bukry, D. \& Monechi, S. 1985. Late Cenozoic silicoflagellates from the Northwest Pacific, Deep Sea Drilling Project Leg 86: Paleotemperature trends and texture classification. In: Heath, G.R., Burckle, L.H. et al. (eds) Initial Reports of the Deep Sea Drilling Project, 86. US Government Printing Office, Washington, DC, 367-397.

Chang, F.H. 2015. Cell morphology and life history of Dictyocha octonaria (Dictyochophyceae, Ochrophyta) from Wellington Harbour, New Zealand. Phycological Research, 63, 253-264.
Chang, F.H., McVeagh, M., Gall, M. \& Smith, P. 2012. Chattonella globosa is a member of Dictyochophyceae: reassignment to Vicicitus gen. nov. based on molecular phylogeny, pigment composition, morphology and life history. Phycologia, 51, 403-420.

Ciesielski, P.F. 1991. Biostratigraphy of diverse silicoflagellate assemblages from the early Paleocene to early Miocene of Holes 689A, 700B, 702B, and 703A Subantarctic South Atlantic. In: Ciesielski, P.F., Kristoffersen, Y. et al. (eds) Proceedings of the Ocean Drilling Program, Scientific Results, 114. Ocean Drilling Program, College Station, TX 49-96.

Deflandre, G. 1950. Contribution à l'étude des silicoflagellidés actuels et fossiles. Microscopie, 2, 1-82.

Dumitrica, P. 2014. Double skeletons of silicoflagellates: Their reciprocal position and taxonomical and paleobiological values. Revue de Micropaléontologie, 57, 57-74.

Gemeinhardt, K. 1930. Silicoflagellatae. In: Rabenhorst, L. (ed.) KryptogamenFlora von Deutschland, Österreich und der Schweiz. Akademische Verlagsgesellschaft, Leipzig, 10, 1-87.

Gleser, Z.I. 1966. Silicoflagellatophycaea. In: Gollerbakh, M.M. (ed.) Cryptogamic Plants of the U.S.S.R., 7. V. A. Komarov Botanical Institute, 1-363. (Translated from Russian by Israel Program for Scientific Translations Ltd, Jerusalem, 1970).

Guex, J. 2006. Reinitialization of evolutionary clocks during sublethal environmental stress in some invertebrates. Earth and Planetary Science Letters, 242, 240-253.

Haeckel, E. 1887. Report on the radiolarians collected by H.M.S. Challenger during the years 1873-1876. Reports of the Scientific Results of H.M.S Challenger during the years 1873-1876, 18, 1-1803.

Henriksen, P., Knipschild, F., Moestrup, Ø. \& Thomsen, H.A. 1993. Autecology, life history and toxicology of the silicoflagellate Dictyocha speculum (Silicoflagellatea, Dictyochophyceae). Phycologia, 32, 29-39.

Jordan, R.W. \& McCartney, K. 2015. Stephanocha nom. nov., a replacement name for the illegitimate silicoflagellate genus Distephanus Stöhr. Phytotaxa, 201, 177-187.

Lemmermann, C. 1908. Flagellatae, Chlorophyceae, Coccosphaerales und Silicoflagellatae. Nordisches Plankton, Botanischer Teil, 21, 25-32.

Ling, H.-Y. 1972. Upper Cretaceous and Cenozoic silicoflagellates and ebridians. Bulletins of American Paleontology, 62, 135-229.

Locker, S. 1974. Revision der Silicoflagellaten aus der Mikrogeologischen Sammlung von C.G. Ehrenberg. Eclogae geologicae Helvetiae, 67, 631-646.

Locker, S. \& Martini, E. 1986. Silicoflagellates and some sponge spicules from the southwest Pacific. In: Kennett, J.P., von der Borch, C.C. et al. (eds) Initial Reports of the Deep Sea Drilling Project, 90. US Government Printing Office, Washington, DC, 887-924.

Mandra, Y.T. 1968. Silicoflagellates from the Cretaceous, Eocene, and Miocene of California, U. S. A. Proceedings of the California Academy of Sciences, 36, 231-277.

Marshall, S.M. 1934. The Silicoflagellata and Tintinnoinea. Great Barrier Reef Expedition 1928-1929. Science Reports, 6, 623-664.

Martínez-López, A., Álvarez-Gómez, I.G. \& Durazo, R. 2012. Climate variability and silicoflagellate fluxes in Alfonso Basin (southern Gulf of California). Botanica Marina, 55, 177-185.

McCartney, K. 1988. SILICO: A computer program for the three-dimensional measurement of silicoflagellate skeletons. Computer \& GeoSciences, 14, 99-111.

McCartney, K. \& Harwood, D.M. 1992. Silicoflagellates from Leg 120 on the Kerguelen Plateau, Southeast Indian Ocean. In: Wise, S.W., Jr., Schlich, R et al. (eds) Proceedings of the Ocean Drilling Program, Scientific Results, 120. Ocean Drilling Program, College Station, TX, 811-831.

McCartney, K. \& Loper, D.E. 1989. Mathematical modeling of Dictyocha and Distephanus skeletal morphology. Paleobiology, 15, 283-298.

McCartney, K. \& Wise, S.W., Jr. 1987. Silicoflagellate and ebridians from the New Jersey Transect, Deep Sea Drilling Project Leg 93, Sites 604 and 606. In. van Hinte, J.E., Wise, S.W., Jr. et al. (eds) Initial Reports of the Deep Sea Drilling Project, 93. US Government Printing Office, Washington, DC, 801-814.

McCartney, K. \& Wise, S.W., Jr. 1990. Cenozoic silicoflagellates and ebridians from Ocean Drilling Program Leg 113: Biostratigraphy and notes on morphologic variability. In: Barker, P.F., Kennett, J.P. et al. (eds) Proceedings of the Ocean Drilling Program, Scientific Results, 113. Ocean Drilling Program, College Station, TX, 729-760.

McCartney, K., Churchill, S. \& Woestendiek, L. 1995. Silicoflagellates and ebridians from ODP Leg 138, Eastern Equatorial Pacific. In: Pisias, N.G., Mayer, L.A. et al. (eds) Proceedings of the Ocean Drilling Program, Scientific Results, 138. Ocean Drilling Program, College Station, TX, 129-162.

McCartney, K., Harwood, D.M. \& Witkowski, J. 2010. A rare double skeleton of the silicoflagellate Corbisema. Journal of Micropalaeontology, 29, 185-186, http://doi.org/10.1144/0262-821X09-020

McCartney, K., Witkowski, J. \& Harwood, D.M. 2011. Unusual early assemblages of Late Cretaceous silicoflagellates from the Canadian Archipelago. Revue de Micropaléontologie, 54, 31-58.

McCartney, K., Witkowski, J. \& Harwood, D.M. 2014a. New insights into skeletal morphology of the oldest known silicoflagellates: Variramus, Cornua and Gleserocha gen. nov. Revue de Micropaléontologie, 57, 75-91.

McCartney, K., Witkowski, J. et al. 2014b. Fine structure of silicoflagellate double skeletons. Marine Micropaleontology, 113, 10-19. 
McCartney, K., Abe, K., Harrison, M.A., Witkowski, J., Harwood, D.M., Jordan R.W. \& Kano, H. 2015a. Silicoflagellate double skeletons in the geologic record. Marine Micropaleontology, 117, 65-79.

McCartney, K., Abe, K., Jordan, R.W. \& Witkowski, J. 2015b. Morphological variation in pike structure in Corbisema (Silicoflagellata) from the Eocene. Journal of Nannoplankton Research, 35, 177-184.

McCartney, K., Abe, K., Witkowski, J. \& Jordan, R.W. 2015c. Two rare silicoflagellate double skeletons of the Star-of-David configuration from the Eocene. Journal of Micropalaeontology, 34, 97-99, http://doi.org/10.1144/ jmpaleo2013-024

Moestrup, Ø. \& Thomsen, H.A. 1990. Dictyocha speculum (Silicoflagellatea Dictyochophyceae), studies on armoured and unarmoured stages. Biologiske Skrifter, 37, 1-22.

Onodera, J. \& Takahashi, K. 2009. Taxonomy and biostratigraphy of middle Eocene silicoflagellates in the central Arctic Basin. Micropaleontology, 55, 209-248.

Perch-Nielsen, K. 1975. Late Cretaceous to Pleistocene silicoflagellates from the southern southwest Pacific, DSDP, Leg 29. In: Kennett, J.P., Houtz, R.E. et al. (eds) Initial Reports of the Deep Sea Drilling Project, 29. US Government Printing Office, Washington, DC, 677-721.

Poelchau, H.S. 1976. Distribution of Holocene silicoflagellates in North Pacific sediments. Micropaleontology, 22, 164-193.

Stradner, H. 1961. Über fossile Silicoflagelliden und die Möglichkeit ihrer Verwendung in der Erdölstratigraphie. Erdöl \& Kohle, Erdgas, Petrochemie, 14, 87-92.

Tsutsui, H. \& Takahashi, K. 2009. Biometry of Distephanus medianostosol (Silicoflagellata) in the sea-ice covered environment of the central Arctic Ocean, summer 2004. Memoirs of the Faculty of Science, Kyushu University, Series D, 32, 57-68.

Tsutsui, H., Takahashi, K., Nishida, S. \& Nishiwaki, N. 2009. Intraspecific morphological variation with biometry of Distephanus speculum (Silicoflagellata). Marine Micropaleontology, 72, 239-250.

Witkowski, J., Bohaty, S.M., McCartney, K. \& Harwood, D.M. 2012. Enhanced siliceous plankton productivity in response to middle Eocene warming at Southern Ocean ODP Sites 748 and 749. Palaeogeography, Palaeoclimatology, Palaeoecology, 326-328, 78-94. 